Vol. 19, n² | 2015

Varia

\title{
Reflections on the relative accessibility of law courts in early modern Europe
}

Griet Vermeesch

\section{OpenEdition}

\section{Journals}

Electronic version

URL: http://journals.openedition.org/chs/1598

DOI: 10.4000/chs.1598

ISSN: 1663-4837

\section{Publisher}

Librairie Droz

\section{Printed version}

Date of publication: 1 November 2015

Number of pages: 53-76

ISBN: 978-2-600-01908-8

ISSN: $1422-0857$

\section{Electronic reference}

Griet Vermeesch, «Reflections on the relative accessibility of law courts in early modern Europe », Crime, Histoire \& Sociétés / Crime, History \& Societies [Online], Vol. 19, $n^{\circ} 2$ | 2015, Online since 01

November 2017, connection on 30 April 2019. URL : http://journals.openedition.org/chs/1598 ; DOI : $10.4000 /$ chs. 1598 


\title{
Reflections on the relative accessibility of law courts in early modern Europe
}

\author{
Griet Vermeesch'
}

Cet article examine les pratiques juridiques sous l'angle de l'accès aux tribunaux en Europe, à l'époque moderne. L'état des connaissances concernant les possibilités et l'usage des recours au judiciaire par les fractions sociales inférieures pour régler les différends, ainsi que leur évolution au cours de la période, prend en compte l'Angleterre et la France, et, dans une moindre mesure, le Saint-Empire Romain, l'Italie, l'Espagne et les Pays-Bas. À ce jour, l'historiographie ne permet pas de donner des réponses tranchées à ces questions, mais ouvre des perspectives pour une enquête de ce type du fait qu'elle apporte des arguments en faveur aussi bien d'une réponse pessimiste que d'une réponse plus optimiste. L'article examine le possible impact de la fragmentation juridique, de l'organisation judiciaire et du processus de juridicisation et, en conclusion, propose des pistes de recherches nouvelles tendant à une analyse socialement et chronologiquement différenciée de la manière dont les gens ordinaires usent de la justice pour négocier leurs relations et leurs problèmes socio-économiques.

In this article historiography on early modern legal practice is reviewed regarding the relative accessibility of law courts in early modern Europe. References on England and France and to a lesser extent on the Holy Roman Empire, Italy, Spain and the Low Countries are used to assess what is known about the extent to which lower social groups could and did use judicial infrastructure to settle disputes and whether and how this changed during the early modern period. To date, historiography does not allow for clearcut answers to such questions. However, it does offer an opening for such inquiry, comprising elements that lead to a pessimistic as well as a more

$1 \quad$ Griet Vermeesch is currently attached as a postdoctoral fellow at the Research Foundation-Flanders (FWO) to the research group Historical Research into Urban Transformation Processes (HOST) at the History Department of the Vrije Universiteit Brussels, Belgium. She also participates in the Inter University Attraction Pole (IUAP) 'City and Society in the Low Countries 1200-1800'.

Three major publications :

- Oorlog, steden en staatsvorming. De grenssteden Gorinchem en Doesburg tijdens de geboorteeeuw van de Republiek (1572-1680), Amsterdam: Amsterdam University Press, 2006.

- Professional lobbying in eighteenth-century Brussels: The role of agents in petitioning the central government institutions in the Habsburg Netherlands, Journal of Early Modern History, 2012, 16, 95-119.

- Access to justice. Legal aid to the poor at civil law courts in the eighteenth-century Low Countries, Law and History Review, 2014, 32, pp. 673-718.

Current research: postdoctoral fellowship of the Research Foundation - Flanders on a project titled "Access to Justice. Urban legal procedures and the pro bono procedure in the early modern Low Countries (c. 1500-1800)". 
optimistic assessment. The possible impact of juridical fragmentation, the organisation of law courts and of juridification is considered. The article ends with suggestions for new research that aims for a socially and chronologically differentiated analysis of the uses ordinary people made of justice to negotiate their social-economic relations and issues.

\section{INTRODUCTION}

Since the 1970s the discipline of history has benefitted markedly from the opening up of court records as sources for historical research. The establishment of this and similar journals testifies to the historiographical importance of the relationship between the history of society and the history of law. One scholar has even argued that there is a 'judicial turn' in historiography. ${ }^{2}$ Juridical sources have been seen to offer unique opportunities for hearing the voices of social groups that tend to be silent or marginalised in other types of source material and for disclosing social interactions that are difficult to discern from more abundantly available normative sources. ${ }^{3}$ Court records have been extensively used to examine credit relations ${ }^{4}$, wealth distribution ${ }^{5}$, and social relations within neighbourhoods in an urban context. ${ }^{6}$ Moreover, the digitisation of court records promises to unlock new research opportunities for writing a new 'history from below'.

Whereas the history of early modern society is enriched by juridical source material, legal history is increasingly written within its appropriate societal context. This development is primarily due to input from historians who approach the history of legal institutions from a social historical perspective. ${ }^{8}$ To date, the relation between law and society has become a central theme of reflection and research. Related meta-narratives have been formulated, such as that developed by Bruce Lenman and Geoffrey Parker, who argued in 1980 for a process of so-called 'juridification' in their groundbreaking article on 'The state, the community and the criminal law in early modern Europe'. According to Lenman and Parker, people had been reluctant to resort to legal institutions in the beginning of the early modern period but increasingly came to rely on formal criminal law to settle disputes. ${ }^{9}$ Thus law became ever more important for society and vice versa.

Although the concept of 'juridification' remains in use, historiography has in the last decade been enriched by a new concept that allows for a more nuanced approach to the dynamic relation between law and early modern communities. Martin Dinges has formulated the notion of 'uses of justice', or 'Justiznutzung'. ${ }^{10}$ The

\footnotetext{
Blaufarb (2010).

Bercé (1980); Stone (1987, p. 241); Garnot (Ed.) (2006).

4 See for instance The special issue of the journal Continuity and Change 29 (2014) on 'Law Courts, Contracts and Rural Society in Europe 1200-1600'. See also Muldrew (1998).

5 See for instance Shepard, Spicksley (2011).

6 See for instance Phillips (1980), Cohen (2012).

7 Hitchcock, Shoemaker, (2006).

8 See for instance Gatrell, Lenman, Parker (Eds) (1980); Garnot (2000a); McMahon (Ed.) (2008).

9 Lenman, Parker (1980).

10 Dinges $(2000,2004)$.
} 
concept is most familiar in German historiography ${ }^{11}$, but its implications have been acknowledged in publications written in English. ${ }^{12}$ On the strength of his research into police records from eighteenth-century Paris, Dinges has noted that in legal conflicts plaintiffs and defendants alike decisively influenced the course of legal proceedings. In particular, they used the juridical infrastructure in an instrumental way, as part of a wider set of informal mechanisms and means of conflict resolution. Thus parties would ideally settle their conflicts via informal means; in filing a lawsuit the plaintiff first and foremost hoped to compel the defendant to come to an out-of-court agreement. Hence many lawsuits never reached subsequent stages. The concept builds on French historiography - pioneered by Nicole and Yves Castan that elucidates the phenomenon of extrajudicial and infrajudicial conflict settlement and the instrumental ways ordinary people used law courts. ${ }^{13}$ It calls attention to the need for the explicit social contextualisation of legal institutions.

The dynamic interrelation between the law and its users has also been signalled in the seminal research of Christopher Brooks and Richard Kagan on respectively early modern England and Castile. Each has demonstrated how the pronounced extent to which ordinary people from broad layers of society drew on formal legal means to settle conflicts was of great consequence for the development of law courts and of the legal profession during the long sixteenth century. Likewise, each has attributed revolutionary dimensions to the massive upsurge in litigation and its impact on legal administration. ${ }^{14}$ The dramatic proliferation of litigation during the long sixteenth century has been well documented and described for a wide range of European regions and cities and for various law courts, including urban courts, ecclesiastical courts and 'national' courts of appeal..$^{15}$

After the 'legal revolution' of the long sixteenth century, a decline of litigation during the seventeenth and eighteenth centuries has been delineated in a number of law courts across Western Europe on different institutional levels, typically by tallying the number of cases in docket-registers. Here only a limited number of examples suffice to argue for such development. The Reichskammergericht and the Chancery of Valladolid experienced a maximum of cases in the late sixteenth century and a sustained decline until the eighteenth century. ${ }^{16}$ The English Courts of Chancery showed a maximum of cases in the mid-seventeenth century, followed by a marked decline. ${ }^{17}$ Data for the Paris Parlement - that only relate to the late seventeenth and eighteenth century - show a sharp decline as well. ${ }^{18}$ The volume of lawsuits brought before the Court of Holland shows the same trend as the Reichskammergericht and the Chancery of Valladolid: a maximum of cases in the late sixteenth century followed by sustained decline. ${ }^{19}$ This decline has not only been signalled for High Courts. The local court of Bremen showed a maximum of cases

\footnotetext{
11 See for instance Brachtendorf (2003); Fuchs (2005); Wieland (2011).

12 Just a few examples: Mantecon (1998); Hayhoe (2008, ch. 4); MacMahon (2008).

13 Castan (1980); Soman (1982); Garnot (2000b).

14 Kagan (1981); Brooks (1986).

15 Berner (1971); Sharpe (1983); Kagan (1983); Wollschläger (1990); Muldrew (1998).

16 Kagan (1981); Ranieri (1985).

17 Brooks (1989).

18 Kaiser (1980); yet see also Feutry (2012).

19 Le Bailly (2011).
} 
in the early seventeenth century, followed by a period of 'high stagnation'. Decline set in in the early eighteenth century. ${ }^{20}$ In the English ecclesiastical courts there was a marked growth of court business from the mid-sixteenth until the mid-seventeenth century, especially due to testamentary, defamation and tithe causes. From the 1640 s until the early nineteenth century these issues gradually gave less occasion for litigation at church courts. ${ }^{21} \mathrm{~A}$ final example is provided by the local court of the Bailywick of Falaise in Normandy which experienced a decline similar to that of the Parlement of Paris operating at the other end of the French juridical hierarchy. ${ }^{22}$ The decrease in court cases related to the various types of conflicts in question and applied to national, regional, local rural, urban and ecclesiastical courts across Western Europe. ${ }^{23}$ It is clear that examining the ways and extent to which ordinary people drew on the law is essential for understanding its development. Nevertheless, the exact patterns and reasons underlying this decline in litigation are unclear, the question whether it was a European-wide phenomenon is as yet unanswered and its actual impact on legal administration remains to be uncovered. ${ }^{24}$

While there is reasonable agreement about the importance of examining connections between ordinary people, the courts and the law in early modern Europe, it is much less clear exactly which sections of early modern communities actually interacted with the world of the law. The terms 'ordinary people' and 'the community' are broad and thus inadequate for accurate and precise categorization of social groups. Relevant questions include: What sections of early modern populations were in fact able to strategically draw on formal legal infrastructure, for instance to pressure community members they had conflicts with? Whose 'uses of justice' gave rise to the archival series so valuable for social historians? What segments of the population accordingly impacted the development of legal infrastructure? And how did this evolve during the early modern era? Should we conceptualise the socalled 'ordinary people' who used law courts mostly as 'middling groups', or 'lower middling groups', or did lower social groups - who constituted large sections of early modern urban populations - also participate in litigation? What was the lower social barrier of the clientele of early modern law courts?

The topic of access to justice has not been the focus of much research, at least not for the early modern period. ${ }^{25}$ However, the importance of an accurate understanding of the extent to which ordinary people could and did access the law courts is difficult to overestimate. This importance relates to various themes and historiographies on wide-ranging processes, including professionalisation, juridification, state formation and the emergence of high courts, and the increased costs of litigation. It is thought provoking to observe how major transformations in the early modern legal infrastructure influenced its accessibility. Moreover, as I have suggested above

\footnotetext{
20 Wollschläger (1990).

21 Outhwaite (2006, pp. 17-22, 78-94).

22 Dickinson (1976, p. 154).

23 Kaiser (1980); Castan (1983); Kagan (1983); Brooks (1989); Wollschläger (1990); Deceulaer (1996); Champion (1997); Muldrew (1998, pp. 237-8); Shoemaker (2000); Outhwaite (2006).

24 Brooks (1998).

25 For the nineteenth and twentieth centuries, see: Cappelletti, Weisner (Eds) (1978); Renaut (2000). See also Melaerts (2000).
} 
and will argue further, assessing which social groups actually accessed the juridical infrastructure is highly significant for comprehending those transformations.

This essay draws on references on socio-legal history in early modern England and France and to a lesser extent on the Holy Roman Empire, Italy, Spain and the Low Countries. This broad historiography is used to assess what is known about the accessibility of early modern law courts; the extent to which lower social groups did indeed make use of judicial infrastructure to settle disputes and whether and how this changed during the early modern period. Literature on criminal as well as civil law courts on different levels of the juridical hierarchy is included in the analysis. Further complications are created by the fact that, in the early modern context, no straightforward distinction can be made between 'public' or 'formal' law courts on the one hand and informal conflict settlement on the other. In this essay, only law courts that were overseen by representatives of official authority are included in the analysis. Thus the mediating activities of English justices of the peace have for instance been considered as a 'law court', yet the conflict settlement by Flemish guilds or Dutch neighbourhood organisations have not. For the sake of clarity, an overview of the law courts included in the historiography in question is provided in an annex to this article.

This essay consists of three sections. I will first reflect on what historiography tells us about the relative accessibility of early modern law courts and will make a case for allegedly limited accessibility. I will then draw claims for a more nuanced assessment from that historiography. The review of literature will show that, although there are but few references on the actual topic of accessibility of early modern law courts, historiography on early modern legal practice nonetheless provides a firm basis from which to initiate new research. In the third and concluding section I will offer a few suggestions regarding what I consider to be the chief questions that can guide research on the accessibility of justice in early modern Europe.

\section{A PESSIMISTIC ASSESSMENT}

Contemporaries expressed myriad complaints about, among other things, the costs of litigation, the slowness of procedure, the growing complexity of both procedural and substantive law and the incompetence and pettifoggery of court officials. In England, such complaints gave rise to a popular movement for law reform during the mid-seventeenth-century constitutional crisis. Pamphlet campaigns arose targeting the allegedly arbitrary procedures of the so-called prerogative courts (among them the Court of Chancery), which exercised the discretionary powers of the monarch. Pamphlets also criticized other aspects of the legal system, including the fact that pleadings at common law courts were conducted in an old French jargon instead of English, the byzantine complexity of the court system, that people were imprisoned for debt and that obtaining justice was far too expensive and time-consuming for common people. ${ }^{26}$

Similar disapproval and distrust of the legal system was widespread on the continent. In France, the 'cahiers de doléance' of 1789 'exhibited near unanimity

$\overline{26}$ Veall (1970). 
in their dissatisfaction with the French system of justice at the local level'. ${ }^{27}$ Complaints had also arisen in earlier centuries. Of particular influence were the early seventeenth-century writings of Charles Loyseau entitled Discours de l'abus des justices de village. Loyseau condemned the local seigniorial courts as being a redundant jurisdictional echelon staffed by incompetent officials who charged exorbitant fees. ${ }^{28}$ During the sixteenth to eighteenth centuries repeated efforts were exercised to reform the judiciary. These attempts were generally ineffective, however. ${ }^{29}$

FilippoRanieri, whoexamined sixteenth-century uses of the Reichskammergericht, stated that the seeming interminability of judicial proceedings was proverbial. Numerous contemporaries complained about it. ${ }^{30}$ Also, the alleged greed and corruption of members of the legal profession that also caused procedural delays were the sources of many complaints in several European regions. ${ }^{31}$ Such complaints were also uttered on lower jurisdictional levels. In the seventeenth- and eighteenthcentury Habsburg Low Countries, for instance, the government repeatedly organised surveys into the cost of litigation at lower courts and the work of legal professionals, who were deemed responsible for the delays in justice. ${ }^{32}$ In fact, procedural lethargy is a common and well-known problem for legal systems across time and space. ${ }^{33}$

How justified were these complaints? A pessimistic assessment of the relative accessibility of law courts in early modern Western Europe is informed by at least three features of early modern justice: firstly, juridical fragmentation; secondly, the institutional arrangement of law courts; and thirdly, the complexity of judicial procedure.

The highly fragmented nature of early modern jurisdictions severely impacted their accessibility. Today, historians characterize early modern states as so-called composite states because they consisted of manifold units that lacked geographical and institutional consistency. ${ }^{34}$ Thus the incremental processes of state formation resulted in the continuation of power elites at local, regional and 'national' levels who wielded overlapping legislative and legal authority. ${ }^{35}$ This resulted in so-called 'legal pluralism' : a complex amalgamation of royal, feudal, ecclesiastical and urban jurisdictions that more often than not overlapped and was a source of undue delays in judicial proceedings. For instance, increasing stages of appeal procedures had a dilatory effect and thus impeded the accessibility of judicial procedures. Moreover, the overlapping jurisdictions of courts that drew on different sources of law resulted in parallel lawsuits at different courts, thereby increasing the costs and time of litigation. In his research into the local courts of early seventeenth-century Wiltshire, Martin Ingram has identified various litigants who embarked on so-called 'flanking

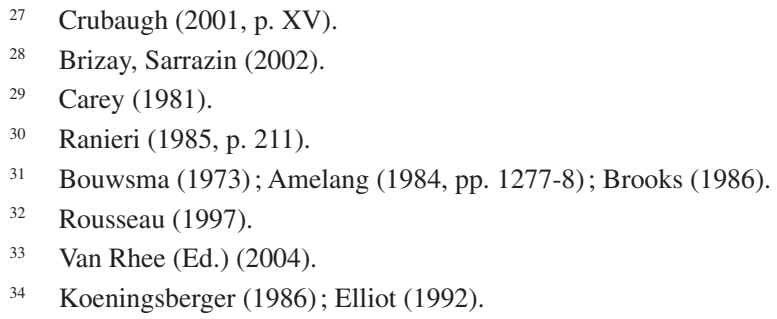

35 See for the late medieval Low Countries, and for early modern France and England: Hugo De Schepper and Jean-Marie Cauchie (2000); Durand (2000); Holmes (2000). 
attacks'. These barratrous parties initiated lawsuits at the central courts in London as a means to retaliate against plaintiffs at the local courts. ${ }^{36}$ In France, the 'cahiers de doléance' of 1789 also critiqued the large number of seigniorial courts. An especially absurd example was the parish of Torxé, in the region of Aunis and Saintonge in Southwestern France, where no less than nine courts administered the legal business of a single parish. ${ }^{37}$ The consequence was that judges as well as other officials of those courts accumulated offices of various seigniorial courts and often treated cases in the seat of the royal baillage where they lived, instead of the village where the court was supposed to operate. Paradoxically, French litigants had consequently to cross long distances to take legal recourse, because of the presence of multiple law courts in their vicinity. ${ }^{38}$

Juridical fragmentation also concerned social status : the social status of litigants was crucial for the kind of justice they received, and this indicates inequality before the law. The multiple types of jurisdictions thus also paralleled class-ridden societies that hailed the principle of unequal status. ${ }^{39}$ To give just one example, Nicole Castan has examined the exceptional courts (presided by the Provosts of the Marechaussée) that were established in eighteenth-century France for the purpose of putting vagrants on trial. ${ }^{40}$ These courts contrasted greatly with the so-called 'Tribunaux de Point D'Honneur' that had been set up in 1602; these courts were for social groups at the other end of the social spectrum, and served notably for counteracting duels between noblemen. ${ }^{41}$ Inequality before the law was thus common and accepted in the early modern context.

Related to this, the law has been depicted as an element of elite culture that helped to reinforce social hierarchies and thus principally to protect the interests of elites. This interpretation was central to influential publications dating from the late 1970s and 1980s, for instance, those of E.P. Thompson and Douglas Hay, who explored first and foremost criminal law. A historiography has emerged, for instance, in which crimes by the labouring poor have been studied as forms of resistance, in defence of customary modes of labour, to the development of capitalism. The law, in turn, was an instrument to increase labour discipline, such as the criminalisation of what was considered as defiance of labourers against their employers, for instance when bargaining for better wages; the criminalization of unilateral breach of labour contracts by employees; or the criminalization of gaining access to common grounds to supplement household income. ${ }^{42}$ Such interpretation of the hostile relation between the law and the lower social groups in society is also at the fore in more recent works, such as Anthony Crubaugh's analysis of seigniorial justice in Southwestern France. He considers the ways such justice was used in defence of seigniorialism and for maintaining law and order and estimates that these courts

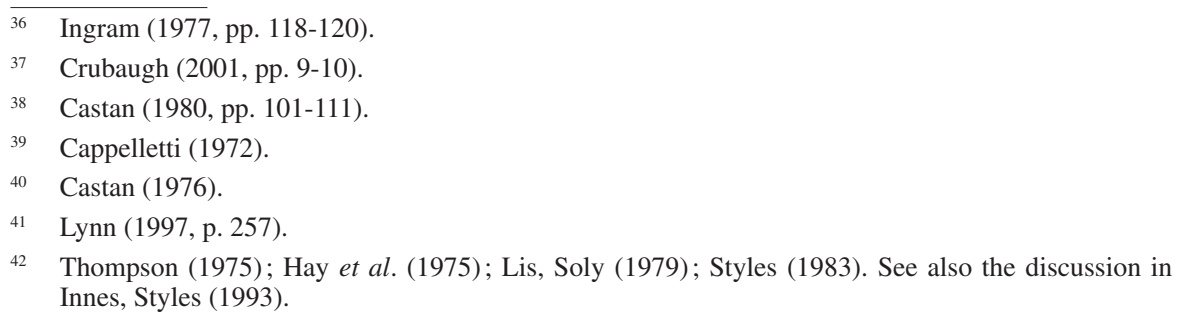


were largely inaccessible for ordinary rural Frenchmen ${ }^{43}$. Even Jim Sharpe, who considered the law in seventeenth-century England as part of 'popular culture', ended his nuanced and influential 1985 essay on 'the people and the law' with the remark that 'the law as a whole represented an important means of transmitting the wishes and aspirations of authority into the popular consciousness' ${ }^{44}$

A second element that affected accessibility involved the institutional arrangement of early modern law courts that was partly responsible for the costliness and slowness of judicial proceedings. For instance, judges and numerous other court officials typically bought their positions and consequently considered them their property, a system of sale of offices termed 'venality'. They therefore expected to be adequately rewarded, and so demanded a range of fees from litigants. Moreover, officeholders usually employed deputies who did the actual work for minor fees but were difficult to monitor. Accordingly, venality allegedly caused early modern law courts to be inefficient, slow and expensive. Additionally, as owners of their posts, court officials unbendingly opposed reforms that would render justice speedier, cheaper, and thus more accessible. ${ }^{45}$ During the Ancien Régime the fact that litigants were responsible for paying the wages of court officials may well have caused lawsuits to be excessively expensive. Contemporaries complained that court officials, who received fees on the basis of work done, organised that work in ways that would maximize the fees they would be paid. ${ }^{46}$ Between 1680 and 1750, the costs of litigation in English central courts doubled. ${ }^{47}$ The rising costs likely deterred many potential litigants from pursuing litigation.$^{48}$ Based on evidence from England, Dinges claims that occasional 'tariff reductions sometimes tripled the number of accusations' ${ }^{49}$

A third reason for decreasing accessibility is the ostensible process of jurifidification mentioned in the introduction of this article. The phenomenon is known in German historiography as 'Verrechtlichung'. ${ }^{50}$ This process entailed developments towards centralization, professionalization and formalization of dispute settlement. Thus while dispute settlement in the beginning of the period typically drew upon informal forms of arbitration and used customary law that litigants were familiar with, state-sponsored formal judicial means such as learned law and statutory law increasingly came to the fore during the early modern period. ${ }^{51}$ Law accordingly became less transparent for potential users and thus less appealing and viable. Indeed, the complexity of formalism of both substantive law and procedural law could be discouraging. In English Common Law courts, plaintiffs would begin judicial proceedings by obtaining a writ, a formal written order, invoking the court's jurisdiction and advancing the cause of their action. A wide array of writs could be chosen. As the specific writ determined the subsequent course of the proceedings, selecting the wrong type of writ could result in legal defeat, no

\footnotetext{
Crubaugh (2001).

4 Sharpe (1985, p. 264).

44 Carey (1981, pp. 10-18); Horwitz (2002).

46 Amelang (1984, pp. 1277-1278); Follain (2005).

47 Brooks (1989, pp. 375, 377-382).

48 Champion (1997, pp. 184-186).

49 Dinges (2004, p. 168).

50 See for instance Stollberg-Rillinger (2001).

51 Lenman, Parker (1980); Eibach (2007).
} 
matter how justified the plaintiff's case. This deficiency and rigidity of the Common Law courts led to the establishment of so-called equity courts, which accordingly applied rules of equity. Over time, however, equity courts developed a distinct body of law that similarly lacked transparency and was formalistic..$^{52}$ Even experts found the complexity of the law daunting. The seventeenth-century English law reformer Matthew Hale revealingly exclaimed that 'the source of law was as undiscoverable as of the Nile'.$^{53}$ Likewise, legal proceedings were often conducted in languages other than the vernacular which was hardly helpful in terms of transparency. In French law courts Greek and Latin were used up until the sixteenth century. ${ }^{54}$ Old French, known as 'Law French', which dated from the twelfth century, was used in English common law courts until the seventeenth century. ${ }^{55}$

Thus, litigants increasingly needed learned jurists who could help them not only in mobilising and interpreting the law for their particular case but also in navigating the sometimes excessively formalistic court procedures. ${ }^{56}$ It is to no surprise, then, that during the early modern era a new professional group of legal practitioners emerged who steered litigants through the various stages of judicial proceedings. The rise of the legal profession has been amply described for several Western European countries. ${ }^{57}$ To be sure, the rising litigation rates were only partly responsible for the rise of jurists. The emergence of a wide range of governmental institutions also facilitated employment for mounting numbers of jurists. ${ }^{58}$ The rise of barristers and solicitors inadvertently reduced the accessibility of judicial proceedings, as engaging the assistance of legal spokesmen increasingly became a necessity to wage a lawsuit. In addition, the previously noted poor reputation of jurists concerning corruption and greediness was not helpful in extending the services of legal spokesmen to come within the reach of lower social groups.

The inadequate availability of legal aid for the poor likewise hampered accessibility. Such aid has its origins in ecclesiastical law. ${ }^{59}$ In canon law the 'personae miserabiles' were entitled to summary procedures out of consideration for their being less able to afford legal fees, being less familiar with formal law and the fact that their conflicts generally related to minor issues. ${ }^{60}$ During the late Middle Ages and early modern times secular law courts similarly adopted a limited range of facilities, such as the possibility of summary proceedings, exemption of court fees and free assistance by legal spokesmen. ${ }^{61}$ However, such aid was always and explicitly granted provisionally

\footnotetext{
$52 \quad$ Van Caeneghem (1972, pp. 25-28, 43-45).

53 Quoted by Veall (1970, p. 31).

54 Kapp (2005).

$55 \quad$ Veall (1970, pp. 226-227).

56 On the role of legal spokesmen in interpreting the law see for instance: Dolan (ed.) (2005); On the formalistic nature of early modern judicial proceedings : Oestmann (ed.) (2009).

57 Prest (ed.), (1981); Amelang (1984); Brooks (1986); Lemmings (1990); 'L'assistance (1997/8); Dolan (2012).

58 See for instance for France, Breen (2007).

59 Brundage (1988, pp. 170-2 and 176, footnote 12); Brundage (1992).

60 Elsener (1976); Helmholz (1996, pp. 128-32).

61 For the Holy Roman Empire and France: Schott (1899, pp. 23-30); Dreyfuss, (1904); Humborg (1999, p. 8); Vicq (2001); For Spain: Kagan (1981, pp. 13, 66-67); For Italy: Cappelletti (1972, p. 240); Cerutti (2007).
} 
and on the condition that circumstances indeed warranted it. If, in the course of the lawsuit's proceedings, the position of the opposing party gained conclusive leverage, the provisioning of legal aid could be re-evaluated and even withdrawn. So far, the actual usage by the poor of forms of legal aid has scarcely been examined; however, preliminary research for the eighteenth-century Low Countries has shown that only limited sections of the poor pursued this option. ${ }^{62}$

It was not only the fees to be paid to court officials and legal spokesmen that restricted the accessibility of law courts. Processes of professionalisation and formalisation increased the physical distance litigants had to traverse so as to receive justice. The frequent expression of complaints about the distance to seigniorial courts in France in the 'cahiers de doléance' of 1789 has already been noted. The problem of distance was even more pressing in England where the state judicial apparatus was characterised by unusual centralisation. Tim Stretton has shown that most litigants pleading 'in forma pauperis' at the Elizabethan Court of Requests were from the vicinity of London. Thus, apart from fees payable to the law courts, the expenses for travel and accommodation were major obstacles faced by people from lower social groups who sought to make use of such formal courts. ${ }^{63}$

Historiography offers ample support for the notion that significant numbers of people shied away from taking legal recourse due to the various complexities of overlapping jurisdictions, judicial procedures and substantive law as well as the costliness of judicial proceedings in terms of both money and time. Social groups who could rely on substantial means and who could mobilise the help of legal practitioners clearly enjoyed an advantage in legal matters. This is evidenced by the conspicuously elitist clientele of superior courts such as the Reichskammergericht in sixteenth-century Germany. ${ }^{64}$ Whereas the high social status of litigants at such High Courts is not surprising, over representation of elites has been similarly detailed for several French as well as Prussian regional and local law courts during the eighteenth century ${ }^{65}$ and even for the mid-eighteenth-century Peacemaker court of the Dutch city of Leiden, which offered markedly inexpensive and uncomplicated arbitration of conflicts. ${ }^{66}$ Thus, it should not be simply assumed that all layers of society accessed justice. The lower social boundaries of users of the judicial system need to be explored.

\section{A MORE OPTIMISTIC ASSESSMENT}

Nonetheless, the masses of archival resources that early modern law courts have bequeathed to us bear witness to the extensive usage sizable numbers of people actually made of those courts. Analyses of the socio-economic composition of court clienteles have shown that during the seventeenth century - as opposed to the eighteenth century - the lower and lower middling groups actively participated in

\footnotetext{
62 Vermeesch (2014); See also Cerutti (2007).

63 Stretton (1998).

64 Ranieri (1985, pp. 229-234).

65 Wollschläger (1982); Piant (2006, pp. 107-109); Mauclair (2008, pp. 307-309); Hardwick (2009, p. 228).

66 Vermeesch (2015).
} 
litigation. Julie Hardwick has demonstrated this for the local courts of Nantes and Lyon, James Shaw has done so for seventeenth-century Venice and Craig Muldrew has done so for the local courts in King's Lynn in England. ${ }^{67}$ As for the increasing complexity and cost of litigation that allegedly deterred people from taking legal recourse, it should be remembered that the legal revolution ensued when Roman canon law and statutory law were already firmly established as sources of law, when litigation fees were already rising and when the legal profession first emerged. How high, then, were these hurdles facing ordinary people who wished to avail themselves of the juridical infrastructure? Historiography offers valuable insights that allow for a more nuanced understanding of the shortcomings of early modern law courts.

First, the lack of a uniform legal system and the overlapping of court jurisdictions constituted not only a threat but also an opportunity for many litigants. Tim Stretton has demonstrated convincingly how women in Elizabethan England could escape the restrictions of the doctrine of coverture by filing lawsuits at courts that used customary or equity law instead of common law. ${ }^{68}$ Richard Kagan has suggested that poor litigants could file lawsuits in first instance at sixteenth-century Castilian chanceries, which allowed them to escape biased judgments by local law courts. ${ }^{69}$ Caroline Castiglione has shown how, in the Roman papal courts, villagers from the Roman countryside defended community rights against their lords. ${ }^{70}$ Many more examples could be given to show how the juridical fragmentation of the composite state mirrored fragmentation of ruling elites along various institutional levels. Thus, ordinary people could make handy use of jurisdictional disputes between elites at the local, regional and supra-regional levels. Recent scholarship in socialpolitical history has emphasized the beneficial effects of the composite nature of the early modern state on the 'political agency' of ordinary people. ${ }^{71}$ Arguably, then, the compositeness of the early modern legal system similarly benefitted the 'legal agency' of those ordinary people. Moreover, overlapping jurisdictions often corresponded to complementary relationships. In eighteenth-century Burgundy, for example, royal courts and seigniorial courts did not necessarily compete for the same clients. Whereas urban elites often preferred the royal courts, rural dwellers usually conducted their judicial business at more local seigniorial courts. ${ }^{72}$ Zoe Schneider has drawn similar conclusions regarding the 'complementary system of justice' of seigniorial and royal courts in Normandy in the years $1670-1740 .^{73}$

Second, the historiography offers various indications of the fairly dynamic and effective performance of law courts; these allow for qualification of such factors as the putatively deleterious effects of venality, litigants being required to pay court officials and the unsavoury reputation of members of the legal profession. Indeed, the many complaints about rising court fees should not be taken at face value. Legal costs accumulated when lawsuits reached advanced stages, yet only a minority of lawsuits ever reached an actual verdict. To mention just a few examples :

\footnotetext{
Muldrew (1993); Shaw (2006); Hardwick (2009).

68 Stretton (1998).

69 Kagan (1981, pp. 98-99).

70 Castiglione (2004).

71 Te Brake (1998); Corteguera (2001).

72 Hayhoe (2008, pp. 29-33).

73 Schneider (2008, p. 12).
} 
in seventeenth-century Nantes and Lyon about one in fifteen lawsuits ended in a sentence. ${ }^{74}$ In England, at King's Lynn's Guildhall court in the 1680s only four per cent of initiated lawsuits were brought to judgement. ${ }^{75}$ As the previously mentioned concept of 'uses of justice' suggests, commencing a lawsuit served as a forceful threat that was often sufficient to convince the alleged offender to negotiate an informal settlement out of court. ${ }^{76}$ In other words, the price and duration of lawsuits were unlikely to deter people from pursuing one.

In similar vein, not all law courts charged court fees or required use of a legal spokesman. Especially in England, summary courts have increasingly become a focus of research. ${ }^{77}$ As Peter King has convincingly asserted, 'the summary courts were the arena in which the vast majority of the population experienced the law'78. The procedures of these courts were inexpensive, informal, private and largely lawyer-free. Admittedly, such courts operated at the fringes of formal law. Yet this does not disprove the fact that formal infrastructure to arbitrate and if necessary adjudicate conflicts could be markedly inexpensive. On the continent, the so-called peacemaker courts and small claims courts have been examined as well. They were equally characterized by transparent procedures and operated practically at no cost. ${ }^{79}$

Even litigants who did have to seek the assistance of legal spokesmen were not necessarily the victims of money-consuming corrupt practices. James Shaw estimates that legal advice could be obtained relatively cheaply in seventeenthcentury Venice, as the city was then 'teeming with lawyers'. Justice at the Giustizia Vecchia was accordingly accessible for the poor as well as for the rich. ${ }^{80}$ Christopher Brooks has convincingly deconstructed the widespread contemporary denigration of the lower branch of the legal profession in sixteenth- and seventeenth-century England. Attorneys and solicitors - as opposed to the barristers, who operated at the higher end of the social spectrum - learned legal practice through apprenticeship, and this placed them on a level with so-called 'mechanical men' such as artisans and tradesmen. In a time when conflicts were considered a social evil, contemporaries were wary that practitioners of such modest social status could play an effective part in the settlement of disputes, not least as they were reliant on fees for their livelihood and thus had a presumed interest in stirring up disagreements. ${ }^{81}$ For earlyseventeenth France, Jeffrey Sawyer has asserted that members of the legal profession were not necessarily averse to legal reform. On the contrary, the cahiers de doléance drawn up at the 1614-1615 Estates General show that legal officials were supporters of legal reform to counter abuses and corruption and to increase the accessibility to legal process. ${ }^{82}$ Current French historiography largely concurs that the seigniorial law courts - which were targets of much denigration by contemporary critics - in fact appeared to function relatively swiftly and cheaply, much to the satisfaction

\footnotetext{
$74 \quad$ Hardwick (2009, p. 76).

75 Muldrew (1998, pp. 255-256).

76 Sharpe (1983); Kagan (1983, p. 146); Muldrew (1993, p. 27); Dinges (2004); Van Meeteren (2006).

77 Hay (2000); King, (2004, pp. 125-172); Dabhoiwala (2006); Gray (2012).

78 King (2004, p. 128).

79 Rousseaux (1991); Denys (1995); Van Meeteren (2006); Denys (2006); Vermeesch (2015).

80 Shaw (2006, ch. 5).

81 Brooks (1986, pp. 178-181).

82 Sawyer (1988).
} 
of litigants who used such courts. ${ }^{83}$ That conclusion similarly appears to apply to French local municipal and royal law courts, the so-called 'justice de proximité', that was generally cheap, swift and conciliatory. ${ }^{84}$

Third, recent historiography cautions against a teleological interpretation of the process of juridification, or 'Verrechtichung', in which communal ideas disappeared in favour of top-down governmental initiatives. ${ }^{85}$ Historians have come increasingly to appreciate that litigants should not be viewed as powerless targets for top-down policies but actively shaped the law and the functioning of law courts. It is likely that the litigants themselves to an important extent instigated the changes, such as centralization and professionalization, which characterize early modern law and law courts. Thus the fact that the legal profession arose during the early modern era was due foremost to the preference of many litigants for hiring such experts. Fabrice Mauclair has described how plaintiffs at the eighteenth-century seigniorial court in la Vallière typically opted to hire a lawyer to defend their cases, even though the 'Code Louis' of 1667 explicitly permitted them to plead without assistance of legal spokesmen in summary cases. ${ }^{86}$

Despite processes of professionalisation, litigants could still wield considerable leverage over judicial proceedings. Joanne Bailey reached this conclusion via examination of court records in combination with private correspondence between litigants and their legal spokesmen at the eighteenth-century consistory court in Durham. The cross-referencing of these 'private' and 'public' documents permitted reconstructing the process of mediation between members of the legal profession and their clients. Bailey found that the court records were firmly founded on information supplied by the parties and that clients determined the course of their lawsuit to a significant extent. ${ }^{87}$ Similarly, for seventeenth-century Rome, comparative research into two civil courts that adopted respectively adversarial and inquisitorial procedures has shown that the results of the trials were analogous. In both kinds of procedures, the parties defined the course of the proceedings ${ }^{88}$ Similarly, a number of historians have drawn attention to the familiarity, frequently underestimated, of ordinary people with jurisprudence. Some historians have adopted the term 'popular legalism' for the well-developed understanding of civil jurisprudence among lower and middling social groups and their participation in judicial proceedings. Michael Sonenscher has emphasized that journeymen in eighteenth-century France recurrently gained successful legal recourse and were familiar with concepts of civil jurisprudence and the intricacies of legal procedure. Hence he refutes the idea that the law was the province of 'elite culture' and that the popular classes' knowledge of the law extended only to holding vague and informal notions of 'customs' ${ }^{89}$ In her research on the shoemakers' guild of eighteenth-century Bologna, Carlo Poni has similarly stressed the many cultural contacts between artisans and legal experts and how 'legal

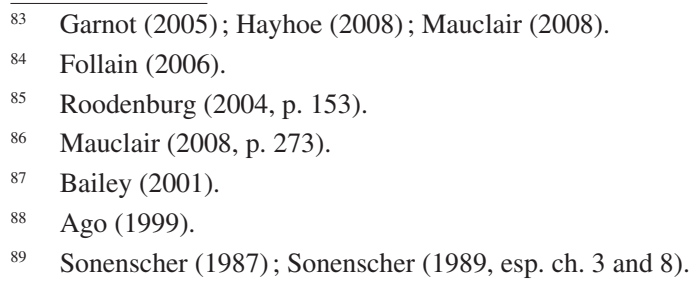


language had penetrated the world of work $\cdot{ }^{90}$ Returning to the relationship between law and custom, Andy Wood has examined how free miners used the customary law to protect their interests in early modern England and how they sharpened their understanding of such law in the course of their struggles with elites. Wood asserts that 'understandings of the law, property and order were open to contest between ruler and ruled' ${ }^{91}$ For Spain, Luis Corteguera has established analogous conclusions for artisans in early modern Barcelona, rebutting the alleged distance and opposition between 'high culture' and 'popular culture' with regard to legal knowledge. ${ }^{92}$

Men were not alone in displaying knowledge of the law. It has been found that women were knowledgeable about the law and its workings and were able to draw on it when needed. Garthine Walker has shown how women who had given birth to illegitimate children in seventeenth-century Cheshire used legal language and concepts to reinforce their defence and claims before the law courts. ${ }^{93}$ Julie Hardwick has underscored how women from broadly defined 'working families' made ample and strategic use of the law to arrange their social economic interests and relations in seventeenth-century Nantes and Lyon. ${ }^{94}$ These feminist historians have gone a step further in conceptualising 'popular legalism' by noting interconnections between the law and the values of 'ordinary people'. Julie Hardwick has introduced the concept of 'litigation communities', a term denoting various parties such as plaintiffs, defendants, court officials as well as witnesses, informal mediators and casual observers who "engaged in a public dialogue, in court or outside of it, about matters that were of critical importance to households, neighbourhoods, and the state'. While the judicial system was an instrument for the state to exert authority over its subjects, this system also allowed for subjects from numerous social strata to participate in 'negotiating the parameters of a wide range of issues' ${ }^{95}$

In short, litigants should not be underestimated in terms of their legal knowledge and capacities for negotiating juridical proceedings and juridical fragmentation to their advantage. Moreover, it is possible that lower social groups could afford at least the initial phases of legal proceedings or that they had access to courts that did not incur many expenses. Lastly, the contemporary denigration of court officials and members of the legal profession should not be interpreted narrowly, literally or uncritically. This historiography is valuable for establishing the possible obstacles that confronted ordinary people seeking to use the judicial infrastructure. It has been made abundantly clear that they accessed the courts, even if often only for the initial stages of legal proceedings. Nevertheless, there remains a historiographical gap concerning which social groups could and indeed did access the courts. As noted in the introduction of this article, notions of 'ordinary people' and 'working households' do not accurately describe social categories. Questions that thus arise include: which sections of ordinary people exerted legal agency, and which sections did not? And how did this develop through time?

\footnotetext{
$90 \quad$ Poni (1989).

91 Wood (1996, p. 278).

92 Corteguera (1998).

93 Walker (2003, pp. 227-237).

94 Hardwick (2009, ch. 2).

95 Hardwick (2009, p. 90).
} 


\section{CONCLUSIONS}

To date, then, historiography does not permit clear-cut answers to questions about the accessibility of early modern law courts, and if and how their accessibility changed during the early modern period. However, the historiography on which this article is based offers a strong starting point for such inquiries. The research under consideration on three aspects of legal infrastructure, i.e. juridical fragmentation, the organisation of law courts and the modes of judicial procedures, inspires new research questions that can help to understand the relative accessibility of early modern law courts. The suggestions for future research that I will present correspond largely to the need for a socially and chronologically differentiated analysis of the uses ordinary people made of justice to negotiate their social-economic relations and issues. I hope to demonstrate that such socially differentiated analysis will help to understand the development of legal change during the early modern era.

First, it is essential to examine more closely how and to what extent ordinary people exploited jurisdictional fragmentation and conflict to their own benefit or experienced such fragmentation as an obstacle for obtaining justice. The fact that diverse law courts were at the disposal of litigants deserves further research. For instance, the role of litigating parties in jurisdictional conflicts between law courts is of interest for assessing forms of 'legal agency', as the analysis of the extent and kinds of case matter for which litigants chose to bypass law courts at lower jurisdictional levels. Such research should incorporate a socially differentiated assessment of experiences of litigants, as not all social groups enjoyed similar levels of 'legal agency'.

Second, new research can elucidate the impact of court organisation on the accessibility of these courts. For instance, a differentiated assessment of court fees is needed. First and foremost the cost of opening a lawsuit should be established in its own right. How costs accumulated in more advanced stages of litigation should be examined separately. Assessment of court fees should thus take into account how law courts were actually used, especially as part of a broader framework of infra- and extrajudicial strategies. This line of research will yield different 'prices' for different law courts, as has been established for the late sixteenth-century Court of Requests versus the Court of Chancery. The latter appeared to be less expensive in the initial stages of lawsuits, yet became markedly more expensive in the advanced stages. ${ }^{96}$ This would have impacted the social profiles of the clientele of the respective law courts. Extending such analyses will help to gain a differentiated understanding of access to justice in early modern Europe.

Similarly, summary courts and instances of arbitration should be studied in more detail, so as to fully establish the extent to which ordinary people drew on such resources to settle disputes. For instance, it could be investigated whether summary procedures were increasingly used in the latter part of the early modern period, when formal law courts became less appealing, as Peter King has suggested for the English case ${ }^{97}$ - or if they rather dissolved to the benefit of more formal procedures, as Simona Cerutti has asserted for eighteenth-century Turin.${ }^{98}$ Clearly,

\footnotetext{
Stretton (1998, p. 83).

97 King (2004, p. 127)

98 Cerutti (1999).
} 
the conclusions of research into one period and place do not necessarily apply to other times and places. How do different social-political contexts of the English countryside and the city of Turin explain these different findings? Establishing the contextual factors that impacted the functioning of summary courts will decidedly improve our understanding of the relation between law and society.

This applies likewise to the assessment of the clientele of summary courts. Research on eighteenth-century England confirms that lower social groups easily found their way to such courts. ${ }^{99}$ Yet research into the Peacemakers Court of mideighteenth-century Leiden (itself also a summary court) has revealed a particularly elite clientele, especially with regard to plaintiffs. As procedures at the court were markedly inexpensive and straightforward, the social-political gap between lower social groups and members of the urban government who acted as judges at the Peacemaker court helps to explain the elite status of the clientele. ${ }^{100}$ A closer analysis of summary courts will help to assess the relative gap between lower social groups and court officials. Again, the relevant social-political context appears to be of marked importance.

Third, further research is needed on the relative impact that litigants had on the course of judicial proceedings. The concept of 'popular legalism' merits further development along the strands developed by Julie Hardwick and Garthine Walker. To what extent did the law reflect values shared by the broader community, and whose values were thus reflected? An analysis of the interaction between legal professionals and their clients is of particular relevance here. For instance, the ways such professionals provided private parties credit to facilitate litigation has thus far scarcely been addressed in historiography. Also, the extent to which clients and legal spokesmen communicated, promises to help understanding the ways in which litigants had a bearing on judicial proceedings, and thus betters our understanding of the nature and scope of popular legalism.

For all these research questions, internationally comparative research would significantly further our understanding of the accessibility of early modern law courts. It is for instance possible that the hurdles to accessing and using formal legal infrastructure were greater in European regions where learned law dominated, such as in the Holy Roman Empire. Interestingly, contemporaries also made international comparisons regarding the practice of using (or not using) legal spokesmen to represent parties in lawsuits. Thomas Platter the younger alleged that in late sixteenth-century Barcelona 'barristers are less numerous than in France'. ${ }^{101}$ During the English popular movement for legal reform it was similarly claimed that there were fewer lawyers in Holland than in England and one could 'get justice as often and as naturally as their cows give milk' ${ }^{102}$ It is worthwhile to take these pronouncements as a point of departure for an internationally comparative analysis of the role of lawyers in (particularly the initial phases of) judicial proceedings. Such analysis would similarly advance our understanding of popular legalism.

A socially differentiated analysis of the uses of justice would help to improve our understanding of changing patterns of litigation during the early modern period,

\footnotetext{
99 Hay (2000); King (2004).

100 Vermeesch (2015).

101 Quoted in Amelang (1984, p. 1267).

102 Pamphleteer Hugh Peters quoted in Veall (1970, p. 206).
} 
notably the legal revolution of the long sixteenth century and the subsequent great litigation decline from the mid-seventeenth century until the end of the eighteenth century. In the long sixteenth century the parties that were to a great extent responsible for the dramatic increase in lawsuits were economically independent members of social groups from the lower middling ranks of society. It is constructive to examine whether these sections of middling groups afforded fewer occasions for litigation after the mid-seventeenth century. An expanded and more effective understanding of changing patterns of litigation will in turn improve our understanding of legal history as a whole. All in all, the issue of 'access to justice' requires research that focuses on the workings of law courts in daily practice, and that approaches the workings of these law courts 'from below', that is, from the perspective of its users, with due attention for the social profiles of those users. In this way a valuable contribution to the legal history of early modern Europe comes into view.

\author{
Griet Vermeesch \\ Vrije Universiteit Brussel \\ Vakgroep Geschiedenis \\ Pleinlaan 2 \\ 1050 Brussel \\ Griet.Vermeesch@vub.ac.be
}

\title{
REFERENCES
}

Ago, R., Une giustizia personalizzata: i tribunali civili di Roma nel XVII secolo, Quaderni Storici, 1999, 34, pp. 389-412.

Amelang, J. S., Barristers and judges in early modern Barcelona: the rise of a legal elite, American Historical Review, 1984, 89, pp. 1264-1284.

Bailey, J., Voices in court: lawyers' or litigants'?, Historical Research, 2001, 74, pp. 392-408.

Bercé, Y.-M., Comportements et mentalités, à travers les sources judiciaires Limousines, $17^{\mathrm{e}}-19^{\mathrm{e}}$ siècles, Bulletin d'histoire moderne et contemporaine, 1980, 12, pp. 77-81.

Berner, S., Florentine society in the late sixteenth and early seventeenth centuries, Studies in the Renaissance, 1971, 18, pp. 227-235.

Blaufarb, R., Conflict and compromise. Communauté and Seigneurie in early modern Provence, The Journal of Modern History, 2010, 82, pp. 519-545.

Bouwsma, W. J., Lawyers and early modern culture, American Historical Review, 1973, 78, pp. 303-327.

Brachtendorf, R., Konflikte, Devianz, Kriminalität: Justiznutzung und Strafpraxis on Kurtrier im 18. Jahrhundert am Beispiel des Amts Cochem, Marburg, Tectum, 2003.

Breen, M. P., Law, city, and king. Legal culture, municipal politics, and state formation in early modern Dijon, Rochester, 2007.

Brizay, F., Sarrazin, V., Le discours de l'abus des justices de village: un texte de circonstance dans une œuvre de référence, in Brizay, F. et al. (dir.), Les justices de village. Administration et justice locales de la fin du Moyen Âge à la Révolution, Rennes, Presses universitaires de Rennes, 2002, pp. 109-122.

Brooks, C. W., Interpersonal conflict and social tension: civil litigation in England, 16401830, in Beier, A. L., Cannadine, D., Rosenheim, J. M. (Eds), The first modern society. Essays in English history in honour of Lawrence Stone, Cambridge, 1989, pp. 357-399.

Brooks, C. W., Lawyers, litigation and English Society since 1450, London and Rio Grande, The Hambledon Press, 1998. 
Brooks, C. W., Pettyfoggers and vipers of the commonwealth. The 'lower branch' of the legal profession in early modern England, Cambridge, Cambridge University Press, 1986.

Brundage, J. A., Legal aid for the poor and the professionalization of Law in the Middle Ages, The Journal of Legal History, 1988, 9, pp. 169-79.

Brundage, J. A., Widows as disadvantaged persons in medieval canon law, in Mirrer, L. (ed.), Upon my husband's death. Widows in the literature and histories of medieval Europe, Michigan, 1992, pp. 193-206.

Cappelletti, M., Giustizia e società, Milano, 1972.

Cappelletti, M., Weisner, J. (Eds), Access to justice, vol. 2, Promising institutions, Varese, 1978.

Carey, J. A., Judicial reform in France before the revolution of 1789, Boston, Harvard University Press, 1981.

Castan, N., Justice et répression en Languedoc à l'époque des Lumières, Paris, 1980.

Castan, N., La justice expéditive, Annales. Économies, Sociétés, Civilisations, 1976, 31, pp. 331-361.

Castan, N., The arbitration of disputes under the 'Ancien Régime', in Bossy, J. (ed.), Disputes and settlements: law and human relations in the West, Cambridge, Cambridge University Press, 1983, pp. 229-260.

Castiglione, C., Adversial literacy. How peasant politics influenced noble governing of the Roman countryside during the early modern period, American Historical Review, 2004, 109, pp. 783-804.

Cerutti, S., Fatti e fatti giudiziari: il Consolato di Commercio di Torino del XVIII secolo, Quaderni Storici, 1999, 34, pp. 413-445.

Cerutti, S., Les «misérables » en droit italien au XVIII e siècle, in Moatti, C. Kaiser, W. (Eds), Gens de passage en Méditerranée de l'Antiquité à l'époque moderne. Procédures de contrôle et d'identification, Paris, 2007, pp. 223-42.

Champion, W.A., Recourse to law and the meaning of the great litigation decline 1650-1750, in Brooks, C. W. (ed.), Communities and courts in Britain 1150-1900, London, 1997, pp. 179-98.

Cohen, E. S., She said, he said: situated oralities in judicial records from early modern Rome, Journal of Early Modern History, 2012, 16, pp. 403-430.

Corteguera, L. R., Popular politics in composite monarchies: Barcelona artisans and the campaign for a papal bull against hoarding (1580-1585), Social History, 2001, 26, pp. 22-39.

Corteguera, L. R., The painter who lost his hat: artisans and justice in early modern Barcelona, The Sixteenth Century Journal, 1998, 29, pp. 1023-1042.

Crubaugh, A., Balancing the scales of justice. Local courts and rural society in Southwest France, 1750-1800, Pennsylvania, 2001.

Dabhoiwala, F., Summary justice in early modern London, English Historical Review, 2006, 121, pp. 796-822.

De Schepper, H., Cauchie, J.-M., Justice, grâce et législation, instruments juridiques de pouvoir princier aux Pays-Bas, 1200-1600, in Padoa-Schioppa, A. (dir.), Justice et législation. Les origines de l'Etat moderne en Europe (Ed. Wim Blockmans and Jean-Philippe Genet), Paris, 2000, pp. 271-313.

Deceulaer, H., Guilds and litigation: conflict settlement in Antwerp (1585-1796), in Boone, M., Prak, M. (Eds), Individual, corporate and judicial status in European cities (late middle ages and early modern period, Leuven, 1996, pp. 171-208.

Denys, C., Les apaiseurs de Lille à la fin de l'Ancien Régime, Revue du Nord, 1995, 77, pp. 13-28. 
Denys, C., Une autre visage de la justice d'Ancien Régime. Les juridictions subalternes de Lille et Douai au XVIII ${ }^{\mathrm{e}}$ siècle, in Follain, A. dir.), Les justices locales. Dans les villes et villages du XVe au XIX ${ }^{e}$ siècle, Rennes, 2006, pp. 295-306.

Dickinson, J., L'activité judiciaire d'après la procédure civile. Le baillage de Falaise, 16681790, Revue d'histoire économique et sociale, 1976, 54, pp. 145-168.

Dinges, M., Justiznutzung als sozialle Kontrolle in der Frühen Neuzeit, in Blauert, A., Schwerthoff, G. (Eds), Kriminalutätsgeschichte: Beiträge zur Sozial- und Kultur geschichte der Vormoderne, Konstanz, 2000, pp. 503-544.

Dinges, M., The uses of justice as a form of social control in early modern Europe, in Roodenburg, H., Spierenburg, P. (Eds), Social control in Europe 1500-1800, Columbus, 2004, pp. 159-175.

Dolan, C. (dir.), Entre justice et justiciables: les auxiliaires de la justice du Moyen Âge au $X X^{e}$ siècle, Saint-Nicolas (Québec), 2005.

Dolan, C., Les procureurs du midi sous l'Ancien Régime, Rennes, PUR, 2012.

Drew, G., Justice at its roots: the current state of research into summary proceedings and petty sessions in England. Invited presentation presented to British crime historians Symposium 3, The Open University, Milton Keynes, 6-7 September 2012.

Dreyfuss, F., L'association de bienfaisance judiciaire, La Révolution Française. Revue d'histoire moderne et contemporaine, 1904, 46, pp. 385-411.

Durand, B., Les instruments juridiques du pouvoir monarchique en France, 1500-1800, in Padoa-Schioppa, A. (dir.), Justice et législation. Les origines de l'État moderne en Europe (Ed. Wim Blockmans and Jean-Philippe Genet), Paris, 2000, pp. 341-367.

Eibach, J., Burghers or town council: who was responsible for urban stability in early modern German towns ?, Urban History, 2007, 34, pp. 14-26.

Elliot, J. H., A Europe of composite monarchies, Past and Present, 1992, 137, pp. 48-71.

Elsener, F., Der 'arme man' (pauper) im Prozessrecht der Grafen und Herzoge von Savoyen, The Legal History Review, 1976, 44, pp. 93-113.

Feutry, D., The historian's mountain of paper: the Parlement of Paris and the analysis of civil suits in the eighteenth century, French History, 2012, 26, pp. 277-296.

Follain, A. (Ed.), Les justices locales. Dans les villes et villages $d u X V^{e}$ au XIX $X^{e}$ siècle, Rennes, PUR, 2006.

Follain, A., L'argent: une limite sérieuse à l'usage de la justice par les communautés d'habitants (XVI'-XVIII' ${ }^{\text {e }}$ siècles), in Garnot, B. (dir.), Les juristes et l'argent. Le coût de la justice et l'argent des juges du XIV $V^{e}$ au XIX $X^{e}$ siècle, Dijon, 2005.

Fuchs, R.-P., Der lange Kampf der Catharina von Dahlhausen um ihre Ehre: Eine Fallstudie zur Justiznutzung von frauen im 16. Jahrhundert, in Westphal, S. (ed.), In eigener Sache. Frauen vor den höchsten Gerichten des Alten Reiches, Köln, 2005, pp. 43-60.

Garnot, B., Justice et société en France aux XVI ${ }^{e}$ XVII et XVIII siècles, Paris, 2000a.

Garnot, B., Justice, infrajustice, parajustice et extra justice dans la France d'Ancien Régime, Crime, Histoire et Sociétés/Crime, History and Societies, 2000b, 4, pp. 103-120.

Garnot, B., Une réhabilitation? Les justices seigneuriales au XVIII ${ }^{\mathrm{e}}$ siècle, Histoire, économie et société, 2005, 2, pp. 61-72.

Garnot, Benoit (Ed.), La justice et l'histoire. Sources judiciaires à l'époque moderne (XVI', XVII ${ }^{e}$, XVIII ${ }^{e}$ siècles) Bréal, 2006.

Gatrell, V.A.C., Lenman, B., Parker, G. (Eds), Crime and the law. The social history of crime in Western Europe since 1500, London, 1980.

Hardwick, J., Family business. Litigation and the political economies of daily life in early modern France, Oxford, Oxford University Press, 2009. 
Hay, D., Master and servant in England. Using the law in the eighteenth and nineteenth centuries, in Steinmetz, W. (ed.), Private law and social inequality in the Industrial Age. Comparing legal cultures in Britain, France, Germany and the United States, Oxford, 2000, pp. 226-264.

Hay, D., Linebaugh, P., Rule, J. G., Thompson, E. P., Winslow, C., Albion's fatal tree: crime and society in eighteenth-century England, London, 1975.

Hayhoe, J., Enlightened feudalism. Seigneurial justice and village society in eighteenthcentury northern Burgundy, New York, 2008.

Helmholz, R. H., The Spirit of Classical Canon Law, Athens, Georgia, University of Georgia Press, 1996.

Hitchcock, T., Shoemaker, R., Digitising history from below: the Old Bailey Proceedings Online, 1674-1834, History Compass, 2006, 4, pp. 193-202.

Holmes, C., Les instruments juridiques du pouvoir et l'État dans l'Angleterre du début de l'époque moderne, in Padoa-Schioppa, A. (ed.), Justice et législation. Les origines de l'Etat moderne en Europe (Ed. Wim Blockmans and Jean-Philippe Genet), Paris, 2000, pp. 315-340.

Horwitz, H., Changes in the law and reform of the legal order: England (and Wales), 16891760, Parliamentary History, 2002, 21, pp. 301-324.

Humborg, M., Das Armenrecht von der Zeit der Kammergerichtsordnung bis heute, Münster, 1999.

Ingram, M., Communities and courts : law and disorder in early seventeenth-century Wiltshire, in Cockburn, J. S. (ed.), Crime in England 1550-1800, London, Methuen, 1977, pp. 110134.

Innes, J., Styles, J., The crime wave : recent writing on crime and criminal justice in eighteenthcentury England, in Wilson, A. (ed.), Rethinking social history: English society 15701920 and its interpretation, Manchester, 1993.

Kagan, R. L., A golden age of litigation: Castile, 1500-1700, in Bossy, J. (ed.), Disputes and settlements: law and human relations in the West, Cambridge, Cambridge University Press, 1983, pp. 145-166.

Kagan, R., Lawsuits and litigants in Castile, 1500-1700, Chapel Hill, The University of North Caroline Press, 1981.

Kaiser, C., The deflation in the volume of litigation at Paris in the eighteenth century and the waning of the old judicial order, European Studies Review, 1980, 10, pp. 309-336.

Kapp, V., Le savoir livresque et/ou le style «naturel». La métamorphose de la culture oratoire du XVI ${ }^{\mathrm{e}}$ au XVII ${ }^{\mathrm{e}}$ siècle, in Faye d'Espeisses, J., Fleury, C., Dix-septième siècle, 2005 , 57, pp. 195-209.

King, P., The summary courts and social relations in eighteenth-century England, Past and Present, 2004, 183, pp. 125-172.

Koeningsberger, H.G., «Dominium Regale» or «Dominium Politicum et Regale», in Koeningsberger, H. G., Politicians and virtuosi : essays in early modern history, London, 1986, pp. 1-26.

L'assistance dans la résolution des conflits. Assistance in conflict resolution. Troisième partie/ Third part. L'Europe médiévale et moderne. Medieval and modern Europe, in Recueils de la Société Jean Bodin pour l'Histoire Comparative des Institutions. Transactions of the Jean Bodin Society for Comparative Institutional History, LXIV, Brussels, 1997.

L'assistance dans la résolution des conflits. Assistance in conflict resolution. Quatrième partie/ Fourth part. L'Europe médiévale et moderne. Medieval and modern Europe, in Recueils de la Société Jean Bodin pour l'Histoire Comparative des Institutions. Transactions of the Jean Bodin Society for Comparative Institutional History, LXV, Brussels, 1998. 
Lemmings, D., Gentlemen and barristers. The Inns of Court and the English Bar, 1680-1730, Oxford, 1990.

Lenman, B., Parker, G., The state, the community and the criminal law in early modern Europe, in Gatrell, V.A.C., Lenman, B., Parker, G., (Eds), Crime and the law. The social history of crime in Western Europe since 1500, London, 1980, pp. 11-48.

Lis, C., Soly, H., Policing the early modern proletariat, 1450-1850, in Levine, D. (ed.), Proletarianization and family history, Orlando et al., 1984, pp. 163-228.

Lynn, J. A., Giant of the Grand Siècle. The French army, 1610-1715, Cambridge, Cambridge University Press, 1997.

Mantecon M., Antonio, T., Meaning and social context of crime in preindustrial times: rural society in the north of Spain, $17^{\text {th }}$ and $18^{\text {th }}$ centuries, Crime, Histoire et Sociétés/Crime, History and Societies, 1998, 2, pp. 49-73.

Mauclair, F., La justice au village. Justice seigneuriale en société rurale dans le duché-pairie de La Vallière (1667-1790), Rennes, Presses Universitaires de Rennes, 2008.

McMahon, R., Introduction, in McMahon, R. (ed.), Crime, law and popular culture in Europe, 1500-1900, Milton, Willan publishing, 2008, pp. 1-31.

Meeteren, A. van, Op hoop van akkoord. Instrumenteel forumgebruik bij geschilbeslechting in Leiden in de zeventiende eeuw, Hilversum, Verloren, 2006.

Melaerts, W., In the shadow of justice: popular uses of the law in urban Normandy, c. 18801905, French History, 2000, 14, pp. 174-200.

Muldrew, C., Credit and the courts : debt litigation in a seventeenth-century Urban Community, The Economic History Review, 1993, 46, 1, pp. 23-38.

Muldrew, C., The Economy of Obligation. The Culture of Credit and Social Relations in Early Modern England, New York, 1998.

Oestmann, P. (ed.), Zwischen Formstrenge und Billigkeit. Forschungen zum vormodernen Zivilprozess. Quellen und Forschungen zur höchsten Gerichtsbarkeit im Alten Reich 56, Cologne, 2009.

Outhwaite, R.B., The rise and fall of the English ecclesiastical courts, 1500-1860, Cambridge, Cambridge University Press, 2006.

Phillips, R., Gender solidarities in late eighteenth-century urban France: the example of Rouen, Social History, 1980, 13, pp. 325-337.

Piant, H., Une justice ordinaire. Justice civile et criminelle dans la prévôté royale de Vaucouleurs sous l'Ancien Régime, Rennes, Presses Universitaires de Rennes, 2006.

Poni, C., Norms and disputes : the shoemakers' guild in eighteenth-century Bologna, Past and Present, 1989, 123, pp. 80-108.

Prest, W. (ed.), Lawyers in early modern Europe and America, New York, 1981.

Ranieri, F., Recht und Gesellschaft im Zeitalter der Rezeption. Eine rechts- und sozialgeschichtliche Analyse der Tätigkeit des Reichskammergerichts im 16. Jahrhundert. I. Teilband, Cologne and Vienna, 1985.

Renaut, M.-H., L'accès à la justice dans la perspective de l'histoire du droit, Revue historique du droit français et étranger, 2000, 78, pp. 473-495.

Roodenburg, H., Social control viewed from below. New perspectives, in Roodenburg, H., Spierenburg, P. (Eds), Social control in Europe 1500-1800, Colombus, 2004, pp. 145-158.

Rousseaux, X., De l'assistance mutuelle à l'assistance professionnelle: Le Brabant (XIV'XVIII ${ }^{\mathrm{e}}$ siècles), in L'assistance dans la resolution des conflits. Troisième partie/Assistance in conflict resolutions. Third Part. Recueils de la Société Jean Bodin pour l'histoire comparative des institutions 64, Brussels, 1997, pp. 129-161.

Rousseaux, X., Le prix du sang versé. La cour des appaiseurs à Nivelles (1430-1665), Bulletin trimestriel du Crédit communal de Belgique, 1991, 175, pp. 45-56. 
Sawyer, J. K., Judicial corruption and legal reform in early seventeenth-century France, Law and History Review, 1988, 6, pp. 95-117.

Schneider, Z. A., The King's bench. Bailiwick magistrates and local governance in Normandy 1670-1740, New York, 2008.

Schott, R., Zur Geschichte des Armenrechts, Jena, 1899.

Sharpe, J. A., 'Such Disagreement betwyx Neighbours': Litigation and Human Relations in Early Modern England, in Bossy, J. (ed.), Disputes and settlements : law and human relations in the West, Cambridge, Cambridge University Press, 1983, pp. 167-187.

Sharpe, J. A., The people and the law, in Reay, B. (ed.), Popular culture in seventeenthcentury England, London and Sydney, 1985, pp. 244-270.

Shaw, J. E., The justice of Venice. Authorities and liberties in the urban economy, 1550-1700, Oxford, 2006.

Shepard, A., Spicksley, J., Worth, age, and social status in early modern England, The Economic History Review 2011, 64, pp. 493-530.

Shoemaker, R., The decline of public insult in London 1660-1800, Past and Present, 2000, 169, pp. 97-131.

Soman, A., L'infra-justice à Paris d'après les archives notariales, Histoire, Économie et Société, 1982, 1, pp. 369-375.

Sonenscher, M., Journeymen, the courts and the French trades 1781-1791, Past and Present, 1987, 114, pp. 77-109.

Sonenscher, M., Work and wages. Natural law, politics and the eighteenth-century French trades, Cambridge, 1989.

Stollberg-Rillinger, B., Abhandlungen und Aufsätze - Rang vor Gericht. Zur Verrechtlichung sozialer Rangkonflikte in der frühen Neuzeit, Zeitschrift für Historische Forschung, 2001, 28, pp. 359-384.

Stone, L., The past and the present revisited, London, 1987.

Stretton, T., Women waging law in Elizabethan England, Cambridge, Cambridge University Press, 1998.

Styles, J., Embezzlement, industry and the law in England, 1500-1800, in Berg, M., Hudson, P., Sonenscher, M. (Eds), Manufacture in town and country before the factory, Cambridge, 1983, pp. 173-205.

Te Brake, W., Shaping history. Ordinary people in European politics, 1500-1700, Berkeley and Los Angeles, 1998.

Thompson, E.P., Whigs and hunters: the origin of the black act, New York, 1975.

Thompson, E.P., Customs in common. Studies in traditional popular culture, New York, 1993.

Van Caeneghem, R.C., History of European Civil Procedure, in Cappelletti, M. (ed.), Civil Procedure vol XVI, Tübingen et al., 1972.

Van Rhee, C.H. (ed.), The law's delay. Essays on undue delay in civil litigation, Antwerp, Oxford and New York, 2004.

Veall, D., The popular movement for law reform 1640-1660, Oxford, Clarendon Press, 1970.

Vermeesch, G., Access to justice. Legal aid to the poor at civil law courts in the eighteenthcentury Low Countries, Law and History Review, 32, 2014, pp. 683-714.

Vermeesch, G., The social composition of plaintiffs and defendants in the Peacemaker court, Leiden, 1750-1754, Social History, 40, 2015, pp. 208-229.

Vicq, P., Une forme originale d'aide judiciaire en Lorraine dans la deuxième moitié du XIII ${ }^{\mathrm{e}}$ siècle : la Chambre des consultations, Revue historique du droit Français et étranger, 2001, 79, pp. 485-506.

Walker, G., Crime, gender and social order in early modern England, Cambridge, Cambridge University Press, 2003. 
Wieland, C.n, Verstaatlichung und Homogenisierung, Justiznutzung und Privilegierung: das frühneuzeitliche Rechtssystem als Motor und Hindernis von Staatlichkeit, in Eich, P., Schmidt-Hofner, S., Wieland, C. (Eds), Der wiederkehrende Leviathan. Staatlichkeit und Staatswerdung in Spätantike und Früher Neuzeit, Heidelberg, Winter, 2011, pp. 181-204.

Wollschläger, C., Civil litigation and modernization: the work of the municipal courts of Bremen, Germany, in five centuries, 1549-1984, Law and Society Review, 1990, 24, pp. 261-282.

Wollschläger, C., Ungleiche Justizgewähr und Zivilprozesshäufigkeit in der Preussischen Ständegesellschaft um 1750, in Bergfeld, C. et al. (Eds), Europäisches Rechtsdenken in Geschichte und Gegenwart. Festschrift für H. Coing, München, 1982, pp. 435-451.

Wood, A., Custom, identity and resistance: English free miners and their law, c. 1500-1800, in Griffiths, P., Hindle, S., Fox, A. (Eds), The experience of authority in early modern England, London, 1996, pp. 249-285.

Wrightson, K., Two concepts of order: justices, constables and jurymen in seventeenthcentury England, in Brewer, J., Styles, J. (Eds), An ungovernable people. The English and their law in the seventeenth and eighteenth centuries, London et al., 1983, pp. 21-46.

\section{ANNEX}

Overview of the range of law courts studied in the historiography that is the basis of this essay.

\begin{tabular}{|l|l|l|l|}
\hline Level & Region & Law court & References \\
\hline \multirow{4}{*}{ Central } & \multirow{2}{*}{ England } & Court of Requests & Stretton (1998) \\
\cline { 2 - 4 } & Germany & Wide range of courts & Brooks (1986) \\
\cline { 2 - 4 } & Italy & Roman papal courts & Ranieri (1985) \\
\hline \multirow{3}{*}{ Regional } & France & Parlement of Paris & Sonenscher (1987/1989) \\
\cline { 2 - 4 } & \multirow{2}{*}{ Spain } & Royal audiencia Barcelona & $\begin{array}{l}\text { Amelang (1984); Corteguera } \\
(1998)\end{array}$ \\
\cline { 3 - 4 } & & $\begin{array}{l}\text { Royal audiencias and } \\
\text { chancellerias Castile }\end{array}$ & Kagan (1981) \\
\hline
\end{tabular}




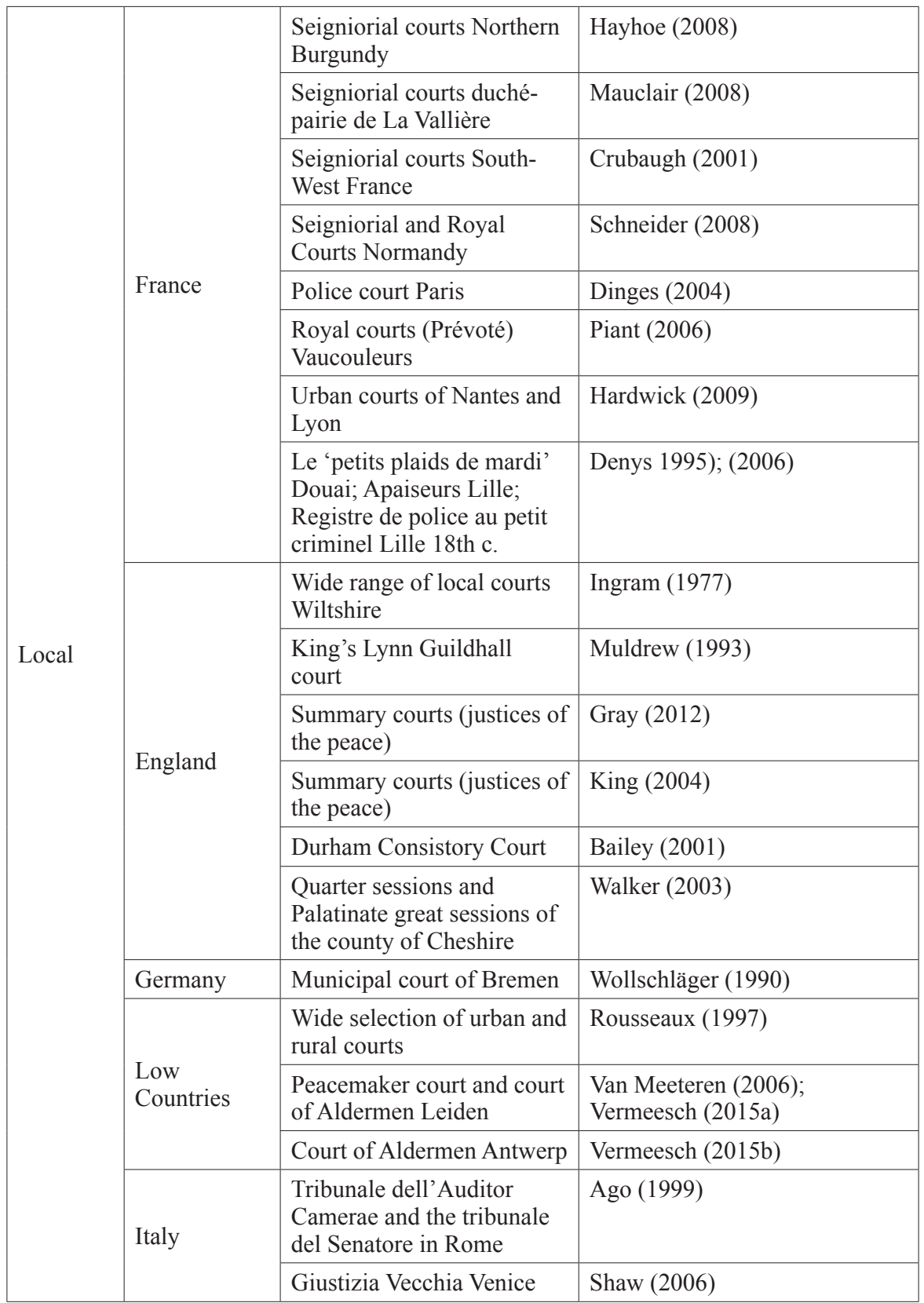

